Kohl: a Journal for Body and Gender Research

Vol. 6, No. 1 (Summer 2020)

\title{
Mourning Sarah Hegazy
}

Rita Slaoui 


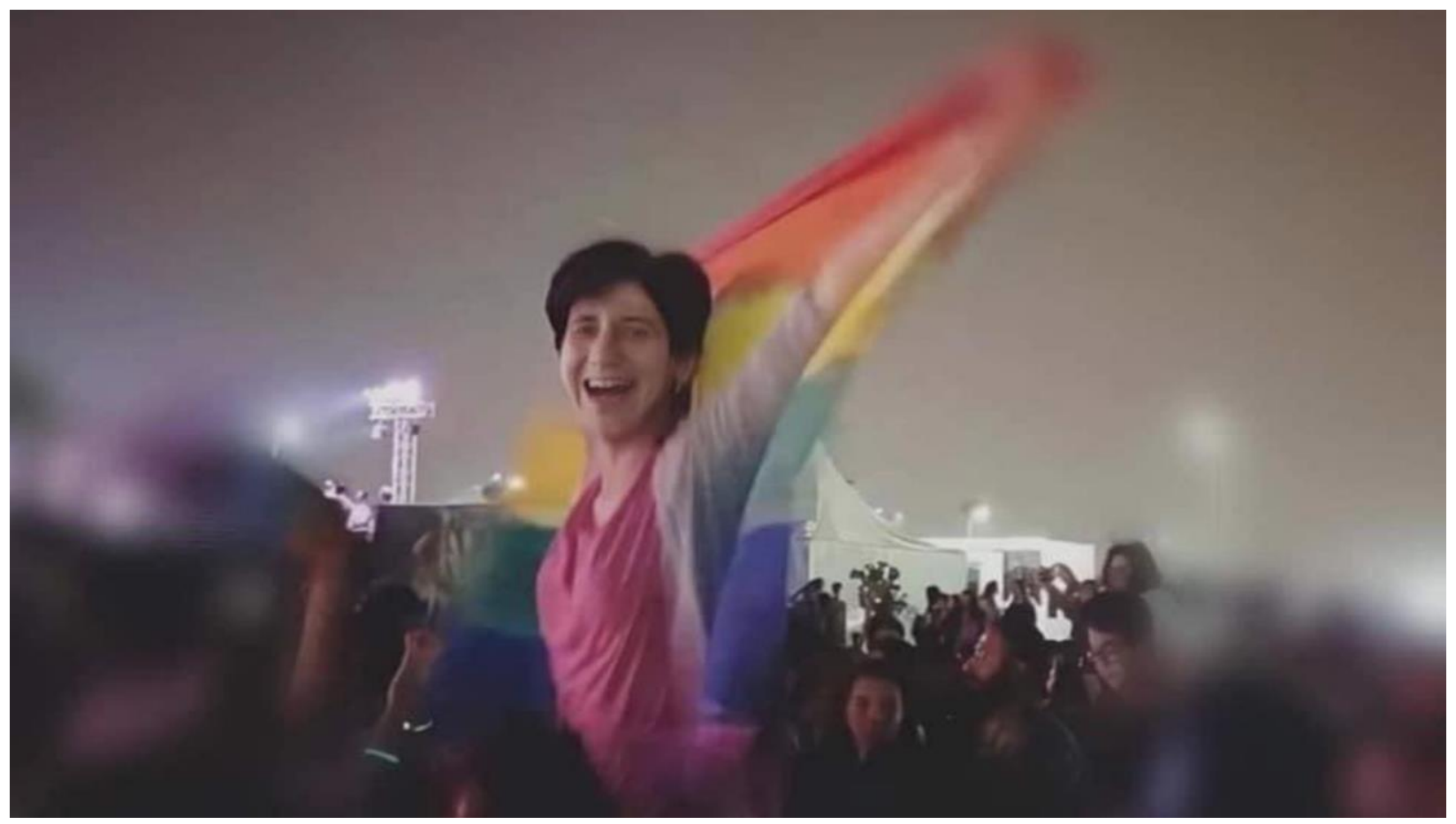

Kohl is mourning Sarah Hegazy's death. We are also celebrating her life of queer, feminist, communist, leftist, anti-classist, and anti-capitalist activism, as are numerous people around the globe. Kohl's work in feminist knowledge archiving and creation is intimately tied to the work of activists in the region, to Sarah's fights and struggles. After raising a rainbow flag in a Mashrou' Leila concert in Egypt, Sarah was harassed by both the public and the oppressive police-state, resulting in her imprisonment. She had to go into exile in Canada, where she suffered from severe mental illnesses due to the trauma she had to endure, and she ultimately decided to take her own life as the world was "horrifically cruel." Sarah was abused by a violent, dictatorial regime and by a society relentless in its abuse, which eventually killed her. It is important for us to care for her, and for the people in our movement and shared struggles.

Sarah's death feels particularly violent and personal as she could have been any of us. Many of us can see ourselves and our friends in her. Her death reminds us of the proximity of danger, which, while deluded by optimism, some of us can sometimes forget. She is a reminder of our conditions in exile, where the illusion of safety is often taken from us as trauma, coldness, fear, and persecution insidiously follow us. She is a reminder to those of us that live in hiding of what awaits us if we decide to stop being quiet. Even for those of us that did not know her, Sarah feels close. And we are collectively mourning.

Mourning is a strange process. It can feel empty, suffocating, angry, devastating. Personally, I did not mourn her death the way you would a friend until I found myself submerged in the sea of hateful, violent comments about her. Then, I understood that even when they kill us, these systems would not stop harassing us, we who also raise fists and flags. These comments felt particularly brutal this time, not because they came as a surprise, but because it felt like they wanted to strip us from our humanity even in our deaths. Once more, I 


\section{Kohl 6.1}

6 was face to face with the violence of police-states and societies who target us, the queers, the feminists, the communists, the revolutionaries.

Mourning also takes diverse forms. Following the news of her death, many gathered to grieve, to celebrate her life and her fights, and to mourn collectively. Many held vigils, signs, and flowers, many talked and cried together. Many of us could not grieve in public, for various reasons, and grieved alone, sometimes lonelily, anonymously. We mourned in front of a coffin, of an embassy, alone in our rooms, or in blog entries.

As Kohl, we want to join in the sadness, anger, mourning, and grieving of her life.

For Sarah, and for all of the Sarahs that we do not hear about. 